FCS8623-Hai

\title{
La Sante Nan Lavi Granmoun: KONSÉY SOU FASON POU-W PRAN VITAMIN ${ }^{1}$
}

Jennifer Hillan ${ }^{2}$

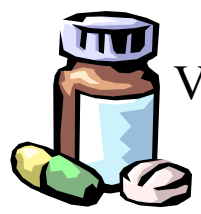

Vitamin, mineral, fèy, avèk lòt sibstans yo se vitamin. Si ou ap pran youn nan yo men kèk konsèy pou-swiv.

\section{Pale avèk doktè-w e famasyen-w}

Pale avèk doktè-w ou famasyen-w avan ou pran nenpòt sipleman pou premyè fwa. Li va di-w:

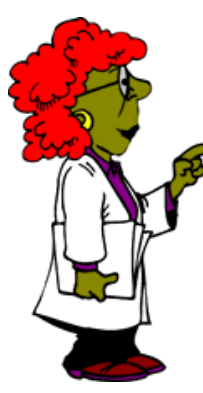

- Konbyen pou-w pran

- Ki lè pou-w pran-1

- Ki rezilta pou-w eskonte

- Entèraksyon avèk lòt sipliman e medikaman

Di doktè-w ki senptom ou genyen lè ou fin pran sipliman-an. Pa pran sipliman lan ankò pou-w ka wè si senptom yo rete.

\section{Achte nan men yon moum ou konnen}

Gade pou wè si pwodwi ki gen lèt U.S. Pharmacopeia (USP) sou li. Sa vle di pwodwi sa-a bon.

\section{Tcheke dat ekspirasyon-an}

Chwazi pwodwi ou kapab wè dat ekspirasyon sou li klèman. Gade dat la pou ka wè si li gen anpil tan avan li ekspirè.

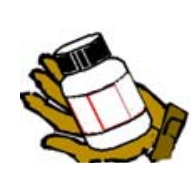

\section{Peye Atansyon!}

Gen pwodwi ki makè "natirèl” o "òganik" gendefwa ki pa bon. Sa yo se reklam, gimmik ki kapab eseye fè-w panse yo pi bon. Atansyon lè ou tande yon pwodwi kapab geri ou vit. Si ou panse bagay sa pakab fè sa yo di li ka fè, li pa bon.

1. This is document FCS8623-HAI, one in a series of the Department of Family, Youth and Community Sciences, Florida Cooperative Extension Service, Institute of Food and Agricultural Sciences, University of Florida, Gainesville, FL 32611. Publication date: March 2004. The English version of this Haitian Creole language leaflet is Healthy Living for Elders: Tips for Taking Dietary Supplements. This leaflet was developed with funding from the Florida Department of Elder Affairs in partnership with state, county, and local agencies. Please visit the EDIS Web site at http://edis.ifas.ufl.edu

2. Jennifer Hillan, MSH, RD, LD/N, former ENAFS nutrition educator/trainer, Department of Family, Youth and Community Sciences, Institute of Food and Agricultural Sciences, University of Florida, Gainesville, FL 32611. English version reviewed by Linda B. Bobroff, PhD, RD, LD/N, professor, University of Florida. Translation by Rodrigue Colas, University of Florida. Reviewed by Jean-Elie Gilles, PhD, French and Haitian Literature, University of Florida. 